\title{
Challenges and Opportunities of Clinicopathological Investigation in Longitudinal Studies of Alzheimer's Disease
}

\author{
M.J. Ball
}

\begin{abstract}
After organizational involvement in a clinicopathological investigation of Alzheimer's Disease for a decade, the present appears an appropriate time to reflect upon both the major challenges encountered as well as the exciting opportunities presented by such a longitudinal study.

Problematic areas have included: (a) brevity of research grant intervals (generally one- or two-year); (b) turnover of support personnel, as a consequence; (c) limited biostatistical and data management expertise dedicated to the Study objectives; (d) limited neuropsychological manpower in this specialized sphere; (e) "distillate" effect of postmortem retrieval, by which only some of the many clinical cases expire during any grant period, only some of those receive autopsy permission, only some of those demonstrate (pure) Alzheimer's Disease neuropathologically, and only some are harvested quickly enough for specialized (e.g. biochemical) analyses; (f) ensuring the scientific optimization of available tissue samples; and (g) paucity of cases dying in the early stages of the illness.

Significant achievements include: (a) demonstration of the opportunities for young researchers committed to careers in behavioral neurology, psychogeriatrics or neurodegenerative pathology; (b) development of improved testing protocols for psychometric, electroencephalographic and neuroradiological evaluation of the demented elderly; (c) ethical enrolment both of a large cohort of Alzheimer patients and a sizeable normative (control) population; (d) public cooperation permitting a postmortem compliance rate exceeding $75 \%$; (e) rapid autopsy retrieval times $(50 \%<6$ hours); (f) utilization of human postmortem synaptosomal preparations for neurochemical investigations; $(\mathrm{g})$ availability of fresh autopsy tissues for other specialized techniques (e.g. magnetic resonance spectroscopy, in situ hybridization); and (h) a collegial forum for the regular exchange of scientific data.

While the challenges to be met are certainly not unique to our Study, the interdisciplinary and longitudinal nature of this approach could magnify their potentially retardatory effect upon research quality. By contrast, however, surmounting these hurdles enables the participant scientists to share in an incomparable opportunity for observational insights into the cellular and pathogenetic mechanisms underlying the cognitive decline of Alzheimer patients. The vigour with which my numerous collaborators at the University of Western Ontario meet such challenges may serve as a model for other Alzheimer centres where a similar research system is likewise expected to justify the anticipation of its supportive funding agencies, and of the patients whom we are pledged to comfort.
\end{abstract}

RÉSUMÉ: Les défis et les opportunités de l'investigation clinicopathologique dans les études longitudinales de la maladie d'Alzheimer. Après avoir été impliqué pendant dix ans au niveau organisationnel dans une investigation clinicopathologique de la maladie d'Alzheimer, le moment me semble opportun de réfléchir sur les défis majeurs ainsi que sur les chances excitantes qu'offre une telle étude longitudinale.

Les domaines dans lesquelles nous avons rencontré des problèmes incluent: a) la brièveté des périodes pour lesquelles des octrois sont accordés (sur une période de un ou deux ans, généralement); b) avec, comme conséquence, un roulement au niveau du personnel de soutien; c) une expertise limitée dans le domaine du traitement des données et de l'analyse biostatistique consacrés aux objectifs de l'étude; d) un personnel limité dans le domaine spécialisé de la neuropsychologie; e) un effet de "distillat" de la récupération des cas en post mortem: seulement quelques-uns des nombreux cas cliniques décèdent pendant une période donnée couverte par une subvention et on n'obtiendra la permission pour l'autopsie que pour un certain nombre de patients décédés; parmi eux, la neuropathologie sera caractéristique d'une maladie d'Alzheimer seulement dans un certain nombre de cas et seulement quelques-uns des

From the Dementia Study Laboratory, University Hospital; Departments of Pathology, Clinical Neurological Sciences and Psychiatry, University of Western Ontario, London, Ontario

Reprint requests to: Dr. M.J. Ball, Director. Dementia Study Laboratory, University Hospital, Departments of Pathology, Clinical Neurological Sciences \& Psychiatry, University of Western Ontario, London, Ontario N6A 5C1 
cerveaux sont prélevés assez tôt pour pouvoir procéder à des analyses spécialisées (i.e. analyses biochimiques); f) la difficulté de s'assurer d'une utilisation scientifique optimale des échantillons de tissus prélevés; et g) la rareté des cas qui décèdent dans les premier stades de la maladie.

Parmi les réalisations importantes, notons: a) la démonstration qu'il y a de la place pour de jeunes chercheurs qui désirent s'engager dans une carrière de recherche en neurologie comportementale, en psychologie ou en pathologie des maladies neurodégénératives; b) le développement de protocoles améliorés pour l'évaluation psychométrique, électroencéphalographique et neuroradiologique des vieillards déments; c) le recrutement dans des conditions conformes à l'éthique, d'une grande cohorte de patients atteints de la maladie d'Alzheimer et d'une population normale (servant de population témoin) assez nombreuse; d) la coopération du public permettant d'obtenir un taux d'autopsie excédant $75 \%$; e) la récupération rapide du matériel d'autopsie $(50 \%<6$ heures); f) l'utilisation des préparations de matériel d'autopsie pour l'étude des synaptosomes en neurochimie; g) la disponibilité du matériel d'autopsie frais pour l'application d'autres techniques spécialisées (e.g. la spectroscopie par résonance magnétique, l'hybridation in situ); et h) une tribune collégiale permettant des échanges de données scientifiques sur une base régulière.

Même si les défis à relever ne sont pas exclusifs à notre étude, leur effet potentiel de retarder l'amélioration de la qualité de la recherche peut être amplifié par la nature interdisciplinaire et longitudinale de cette approche. A l'opposé, cependant, le fait de surmonter ces embûches rend le chercheur capable de prendre part à une situation qui offre une opportunité incomparable pour permettre, grâce à l'observation, une appréciation des mécanismes cellulaires et pathogéniques profonds de la détérioration cognitive chez les patients atteints de la maladie d'Alzheimer. La vigueur avec laquelle mes nombreux collaborateurs à l' "University of Western Ontario" font face à ces défis peut servir de modèle à d'autres centres où il se fait de la recherche sur la maladie d'Alzheimer et où l'on attend également d'un système de recherche similaire au nôtre qu'il justifie les attentes des agences de financement qui le supportent et celles des patients que nous nous sommes engagés à réconforter.

Can. J. Neurol. Sci. 1986; 13:452-455

Since the late 1960 's, the author has been investigating neuropathological aspects of Alzheimer's disease and related neurodegenerative conditions. In 1977, acceptance of my invitation to clinical and basic science colleagues at the University of Western Ontario resulted in our founding the Dementia Study Group, the primary mandate of which is to bring multidisciplinary talents to bear upon a clinicopathological investigation of Alzheimer's disease. Since the author has served as the director of this longitudinal study and the principal investigator for its major research grants for the first decade of this interdisciplinary effort, it is now appropriate for me to share with other research groups some of the notable challenges we have encountered, as well as some of the exciting opportunities which continue to be presented by this prospective, organizational arrangement.

\section{Challenges encountered}

Given that none of the participants in the Dementia Study Group had had any prior experience with a multidisciplinary, longitudinal investigation of senile dementia, it is hardly surprising that a number of problematic areas have arisen. The brief but candid review of these which follows is prompted by the ethical imperative of all researchers to learn from our (honest) errors and share this information for the benefit of our confreres.

Brevity of research grant intervals causes a recurring difficulty. Most funding agencies provide financial support for only a one or two-year period, occasionally for three years. An inordinate amount of time and effort was therefore expended by our Study Group on the planning and submission of research grant application renewals. Funding organizations have naturally been reticent to support new Projects for longer intervals, particularly for a disease whose enormous incidence has only recently been acknowledged. However, improved research productivity from longitudinal investigations of this type will certainly result from project periods of at least five years, especially to established interdisciplinary groups.
As a consequence of the brevity of many of our early grant awards, there has been an inevitable and somewhat frustrating turnover of support staff. An interval of several months is usually required to train such personnel for the laboratory, administrative, or clinical tasks involved. It is therefore extremely inefficient to lose such technicians and project assistants to more secure jobs, often just as their expertise is reaching its zenith. Of course, skilled support staff are only too aware of the recurring crises in grant renewals, and major funding bodies must reevaluate their potential for longer-term commitment to the clinicopathological approach.

Data management, using computer hardware and software, as well as bio-statistical expertise are critical components for any interdepartmental study in which relative strength of multiple correlations between numerous parameters must be weighed. Canadian funding agencies frequently assume this support will be provided by the host Faculty of Medicine. In practice, however, bio-statistical, computer programming, and data management expertise are severely limited by fiscal constraints at most Canadian universities. Superb consultative advice has been available to our Group on an informal basis, but multidisciplinary and longitudinal investigations of this nature properly require full-time support staff dedicated to the specific objectives of such a study.

In this country there are as yet few neuropsychologists with a major commitment to the development of the specialized psychometric instruments needed to study the longitudinal progression of cognitive decline in the organic dementias. As Kaszniak has emphasized elsewhere in this Supplement (A.W. Kaszniak, R.S. Wilson, J.H. Fox and G.T. Stebbins, this volume), psychometric measures used to compare demented patients with healthy controls which may be highly discriminating can by no means be assumed also to show the longitudinal validity required to track the expected deterioration in cognition of Alzheimer patients over many months and years. For example, psychometric instruments sufficiently sensitive to early dementia to 
show very good initial discriminative validity may demonstrate a truncation of variance ("floor effect") as the dementia severity increases over time, and are therefore frequently not the best choice for studies concerned with neurobiological correlates of cognitive deficits in Alzheimer's disease. This is because such truncation in measure variance limits the magnitude of any relationship which may be observed between a given biological (e.g., histological, biochemical) variable and the cognitive measure under study. For these kinds of reasons, in our own Project the earlier clinical choice of the Extended Scale for Dementia and the London Psychogeriatric Rating Scale merits thorough reevaluation. Such improvements will be dramatically facilitated as granting bodies enhance the opportunity for neuropsychological studies of demented patients.

Particularly with an illness in which the expected life span following medical confirmation of diagnosis averages some five to eight years (and not infrequently approaches fifteen years), cellular investigations dependent upon postmortem retrieval of autopsy tissues are by definition constrained by the rate of harvest of this CNS material. Even where the postmortem permission rate is gratifyingly high, only some of the clinical cases documented will expire during any grant interval; the nearest of kin of only some of those patients will permit necropsy; only some of those cases autopsied will show uncomplicated or pure Alzheimer's disease neuropathologically; and only some postmortems can be performed soon enough after death to permit the specialized (e.g. synaptosomal) tissue analyses planned. Cost effectiveness is therefore exceedingly difficult to demonstrate to reviewers of grant proposals, in the face of this "distillate" or winnowing effect on postmortem retrieval.

In North America, there has until recently been a general paucity of available autopsy tissue samples from well-documented clinical cases of Alzheimer's disease and the other organic dementias. Major difficulties in sustained funding have regrettably been encountered by national brain banks, two in the United States and one in Canada. It is therefore crucial to ensure the maximum scientific utilization of harvested brain tissues from any clinicopathological studies, and the special designation by the American National Institutes of Health of ten "centres of excellence" for Alzheimer Research should contribute impressively to the amelioration of this problem. At this University, we continue working to maintain an equitable balance between the requests from local basic scientists and those of cell biologists in several other centres. While these precious tissue samples are provided under the auspices of each Department of Pathology, decisions as to their ultimate distribution are no more the sole jurisdiction of the responsible neuropathologists than they are of the consultant clinicians or the collaborating biochemists. A small Tissue Users' Committee, selected through the office of each Dean of Medicine, may be one mechanism by which the legitimate scientific requirements of all interested parties can be satisfactorily met.

The ease of obtaining autopsy permission, and of course the frequency of expiration, are inversely proportional to the stage or duration of the illness. The large majority of cases harvested in our own Study thus far have been "end-stage" patients, who have suffered from Alzheimer's disease for many years. This fact renders the histological and biochemical dissection of meaningful pathogenetic phenomena much more difficult than in those few instances where the patient has died in the earliest phases of the disease. Since patients are usually not enrolled in such a research Project until the family members have turned to a medical practitioner for help, special efforts should be made to enhance the interaction of such clinicopathological Projects with community-based Memory Clinics, where large numbers of subjects in the very earliest stages of cognitive decline may be studied in vivo and followed sequentially, with greater chance of incidental death from intercurrent illness providing "earlierstage" tissue.

\section{Exciting opportunities}

Despite the challenges created by all of the above problems, a rewarding number of significant achievements have already been accomplished by my colleagues. It is increasingly eviderit that a satisfying research career awaits those younger scientists willing to devote their major efforts to the fields of behavioral neurology, geriatric psychiatry, or the neuropathology of the organic dementias. At this Medical School, many of Canada"s pioneers in these research fields declared a collaborative intent for Alzheimer research in spite of undiminished responsibilitie:s for hospital diagnostic duties, teaching and administrative tasks and private medical practice. Some of our contributions have been substantial, but the Deans of medical schools are ever more aware that acceleration of such progress necessitates the appointment of full-time investigators in these research areas.

Concomitant spin-offs for the health care system in thiis country will also flow, as markedly improved testing protocolls are developed for the neuropsychological, electroencephalographic, and neuroradiological evaluation of senior citizens, to establish more accurately the base-line values for normal aging as well as the criteria for earlier diagnostic acumen in the organic dementias.

The Dementia Study Group at this University has already enrolled more than 300 demented patients and more than 150 normative control subjects, with input from the Human Ethic:s Committee of the University. Efforts at educating the citizenıs of southern Ontario to the nature of this longitudinal study have provided a postmortem compliance rate which exceeds $75 \%$, nearly double that found at many Canadian teaching hospitals. Favourable liaison with the regional chronic care institutionıs and nursing homes has also guaranteed a very rapid autops $y$ retrieval period, in which the postmortem interval $50 \%$ of the time is less than six hours. The ready availability of fresh CN S tissues has enabled our colleagues to pursue a variety of specia lized investigative techniques, including preparation of synaptosomal samples for neurochemical studies; magnetic resonanc:e spectroscopy; and in situ hybridization. Also worthy of com 1mendation is the regularization of a (monthly) scientific mee ting for the collegial exchange of data and new ideas, attende d by all our collaborators and ably chaired by Professor $\mathrm{H}$. Merskey.

\section{Comment}

The multifaceted and longitudinal nature of a clinicopatholog ical approach to Alzheimer's disease can potentially magnif $y$ the retardatory effect of several of the above problems upon the research productivity of such a Group. It is my personal belie $f$, however, that the incomparable opportunity for sharing ou ir observational insights into the pathogenetic mechanisms in Alzheimer's disease will stimulate the participating scientists ; at this University to surmount such hurdles with exemplary vigous: 
By sharing our difficulties as openly as our achievements with colleagues in other research institutions, the Dementia Study Group at the University of Western Ontario can hopefully serve as a model for other Alzheimer centres, where a similar research configuration must ultimately justify the anticipation not only of its supporting granting agencies but also of the participating patients and their families, without whose generous involvement this work would be impossible.

\section{ACKNOWLEDGEMENTS}

This work was supported in part by grants from the United States Department of Health and Human Services, National Institutes of Health (2 R01 AG03047 04A1), the Medical Research Council of Canada (PG21), and Health and Welfare Canada (6606-2889-44). Mrs. Janet Hughes skillfully prepared the manuscript.

The author thanks all members of the U.W.O. Dementia Study Group for their encouragement and support. 